\title{
Family structure assessment of patients in palliative home care
}

Solange Fátima Geraldo da Costa ${ }^{1}$, Regina Célia de Oliveira², Gicely Regina Sobral da Silva Monteiro², Maria Andréa Fernandes ${ }^{1}$, Ana Aline Lacet Zaccara', Gilvânia Smith da Nóbrega

\section{Abstract}

This study aims to examine the family structure of patients in palliative home care in the light of the Calgary Family Assessment Model (CFAM). This is a qualitative research, conducted in the residences of patients enrolled in the Palliative Care Unit and Pain Treatment (PCUP) of a university hospital located in Recife/Pernambuco, Brazil, in the period from May to July 2014. The sample consisted of five patients enrolled in the PCUP and five family caregivers. Data collection was performed through an interviewing technique using two instruments: the genogram and eco-map. The empirical material was analyzed in the light of the Calgary Model of Family Assessment. The application of the Model demonstrated external family structure relationship with the non-existent neighborhood; support network in diverse health, with very strong relationship with the PCUP highlighting the link with nursing professional; weak relationship concerning Basic Health Unit and strong connection to the church. The obtained data suggest that each researched family has demands to be thought of as focus of nursing care and have faith as a resource for coping with the disease. It follows that the application of CFAM has highlighted the intra-family ties and the relations established with the support networks, signaling strategies to optimize patient care without a therapeutic possibility of cure and their family.

Morais ${ }^{3}$, Patrícia Serpa de Souza Batista ${ }^{1}$, Fátima Maria da Silva Abrão²

1 Universidade Federal da Paraíba

2 Universidade de Pernambuco

3 Universidade Federal de Campina Grande

\section{Contact information:}

Ana Aline Lacet Zaccara

”] anazaccara@hotmail.com

\section{Keywords}

Palliative care. Family. Family

Nursing. Nursing models.

\section{Introduction}

In recent decades, the family has experienced a process of transformation in its structure and organization. This can be understood as a complex institution that is part of a group of people organized by the parental and/or coexistence relationship [1]. In this light, the family system is funded from the bonding, love, and respect existing between the individuals who compose it, keeping a place of shelter and safety among its members [2]. Despite all these attributes, it also adds to the family group, the teaching of health behaviors and the caring institution function of its members [3], especially in situations of illness. 
In this sense, the involvement of the family in the care of the individual with a disease that threatens the continuity of life is paramount, especially when attention is implemented at home, cozy, care, protection, respect, resilience environment and proximity to significant people providing dignity of life [4]. Hence the importance of Palliative Home Care Service for the family of patients without healing therapeutic possibilities.

The Palliative Home Care allow to assist the person in disease situation in their environment where they live, respecting the autonomy of the patient, developing a comprehensive care and preparing them to death with the possibility to be close to their loved ones and present in the context which is inserted [5].

It should be noted that care allows such a high degree of humanization to the patient. However, it may result in significant and constant challenges to family, and may cause considerable physical and emotional consequences of the act of caring for a patient without therapeutic possibility of cure can feel like a hard task that can cause imbalance and overload, despite the desire and satisfaction to exercise this caregiving role [5].

The practice of this modality of care requires a multidisciplinary team consisting of physicians, nurses, psychologists, social workers, and physical therapists, among others.[6] Regarding the performance of the professionals that make up that team, deserves to highlight the participation of nurses, since they are professionals who assist the patient and their family more often in the home environment.

Therefore, emplacements on theories and theoretical frameworks in the context of Nursing are very important, to support the assistance that will provide to the patient in palliative care and their families, such as the Calgary Family Assessment Model (CFAM), as the cited model provides an enlarged view of the family, and allows to gather information to support and direct care together with the patient and their family.
The CFAM comprises a multidimensional structure which involves three categories: the structural, covering the internal and external structure of the family; the developmental, comprising stages, tasks, and links; and the functional, which includes the activities of daily living [7].

Considering the relevance of CFAM to subsidize the care of nurses in the family context, it is undeniable the importance of studies that seek to explore the patients family structure in palliative home care, as they are incipient the works produced by nurses in the national and international literature using that model to subsidize the practice of this care modality.

Based on the preciding, the study had as thread the following question: Which is the patient's family structure in palliative home care? To answer this proposed question, the research presents the following objective: to analyze the patient's family structure in palliative home care in the light of the Calgary Family Assessment Model.

\section{Methodology}

Its a qualitative field research and deals with meanings, beliefs, motives, aspirations, values and attitudes arising from social interaction. To guide the proposed study, the researchers considered the criteria included in COREQ instrument (Consolidated criteria for reporting qualitative research) [8]. Such instrument includes important items about the rigor of the scientific method for conducting qualitative studies, particularly regarding the empirical and analytical phases of the research process.

The survey was conducted in the residences of patients enrolled in the Palliative Care Unit and Pain Treatment (PCUP) of a university hospital located in Recife, the capital of Pernambuco state, Brazil. This unit is a service that performs assistance in hospitals and home to users of the Unified Health System SUS that are without therapeutic cure possibilities 
and needing palliative care and pain control. Therefore, it presents a multidisciplinary team consisting of doctor, nurse, nutritionist, psychologist and occupational therapist.

The study population consisted of patients enrolled in the service selected for the proposed study, between the months of June to August 2014 and their family caregivers who received at least one home visit of the researcher responsible for the data collection, in that period. Totaling seven families.

To make the selection of the sample, the following inclusion criteria were adopted: patients in palliative home care aged equal or over 18 years, who were conscious and oriented in the period of data collection. As for the family, they should be aged equal or over 18 years, and being the main caregiver.

As for exclusion criteria, patients in a palliative home care who were not able to participate in the interview in the period of data collection, and family caregivers who were not present during the home visits were excluded from the study sample. According to these criteria, two families were not included, since they did not meet one of the mentioned items.

Thus, the sample consisted of five families, each one represented by the patient under the palliative home care and one family caregiver, for a total of ten participants. It should be noted that the amount of participants was considered satisfactory since the qualitative research [9], the number of subjects is not the central focus but the deepening of the phenomenon to be investigated.

The empirical phase of the study took place from June to August 2014. To enable the collection of data with the study participants, the interview technique was used, based on a predefined script containing questions relevant to the development of two recommended tools by the Calgary Family Assessment Model - the genogram and the ecomap [7].
The genogram is a diagram that shows the family tree and outlines its structure and its history and identifies the health status of each person in the family group, as well as the relationships between them. The eco-map corresponds to a graphical representation, which provides the professional for evaluating the relationship between members, through networks and services used by them [7].

To register the interviews with the study participants, the recording system MP4 player was used. An interview with an average of 30 minutes was held for each family. It was carried out by one of the authors of this work after consent of the patient and family caregivers since they already had prior knowledge of the proposed study at the first home visit. The location of the interview was usually in the patient's room or a placeholder of the room to have no interference from others.

The field diary was used after the interview to elaborate the outline of graphic representations for making the genograms and eco-maps relevant to each family. These outlines were presented to the participants so that they have an overview of their family from the obtained information. The obtained empirical material was analyzed in the light of the Calgary Family Assessment Model, with emphasis on the structural evaluation. This assessment includes three subcategories: internal structure, external structure and context, which will be presented in the discussion item.

It is worth noting that the project that took place this study was submitted to the Research Ethics Committee of the University Hospital Osvaldo Cruz, which received the approval certificate with CAAE registration under number 33705814.7.0000.5192. The researchers considered the ethical observances recommended by the guidelines and regulatory standards for the conduction of studies involving human beings addressed by the National Health Council Resolution 466/2012, in force in the country [10]. In particular, regarding the independence of the study participant. 


\section{Results}

The Calgary Family Assessment Model incorporates dimensions that allow understanding the organization considering the individual subsystem, the subsystem and family supra-system. Thus, we used the instruments recommended by that model, which are the genogram and the eco-map to outline the internal and external structures and context of the study participants families [7].

Focusing on the structural category of the family, the diagrams shown below illustrate the presentation of the results to be able to assess the intra-family ties and the relations established with the support network and the use of the family, providing bases for the assessment of family interactions.

The genogram and eco-map shown in Figure 1 shows the structure of family 01 , i.e., the patient under palliative home care the Mr. AHF (index case). He was born in Olinda/Pernambuco; he is retired, he has 59 years old, and he is Catholic.

Mr. AHF patient is married to Mrs. RS (Main caregiver) 48 years old, Catholic, divorced from her first marriage which had two daughters and a grandson. Concerning the internal structure of the family 1, this consists of Mr. AHF, his wife Mrs. RS, Mrs. MJS mother-in-law, 81 years old, widow, diagnosed with diabetes; MS sister-in-law, 51 years old, widow, with a mental disorder, she has a son GS with 19 years old, who has relationship difficulties and behavioral changes, as well as school abandonment. Thus, considering its composition, this family is classified as large.

Family relationships with more extensive systems of external family structure, regarding the family's relationship with the neighborhood, RS exposed that still do not know them since her time is to dedicate to care for the spouse AHF. The AHF patient is also divorced, he has from this previous relationship two daughters and a son who call to know their health status, according to the statement of his current wife RS

Regarding the support network in health, which can be viewed in the eco-map (Figure 1), the family has a very strong relationship with the PCUP, especially with the doctor and the nurse, and with

Figure 1. Genogram and Eco-map of Family 1.

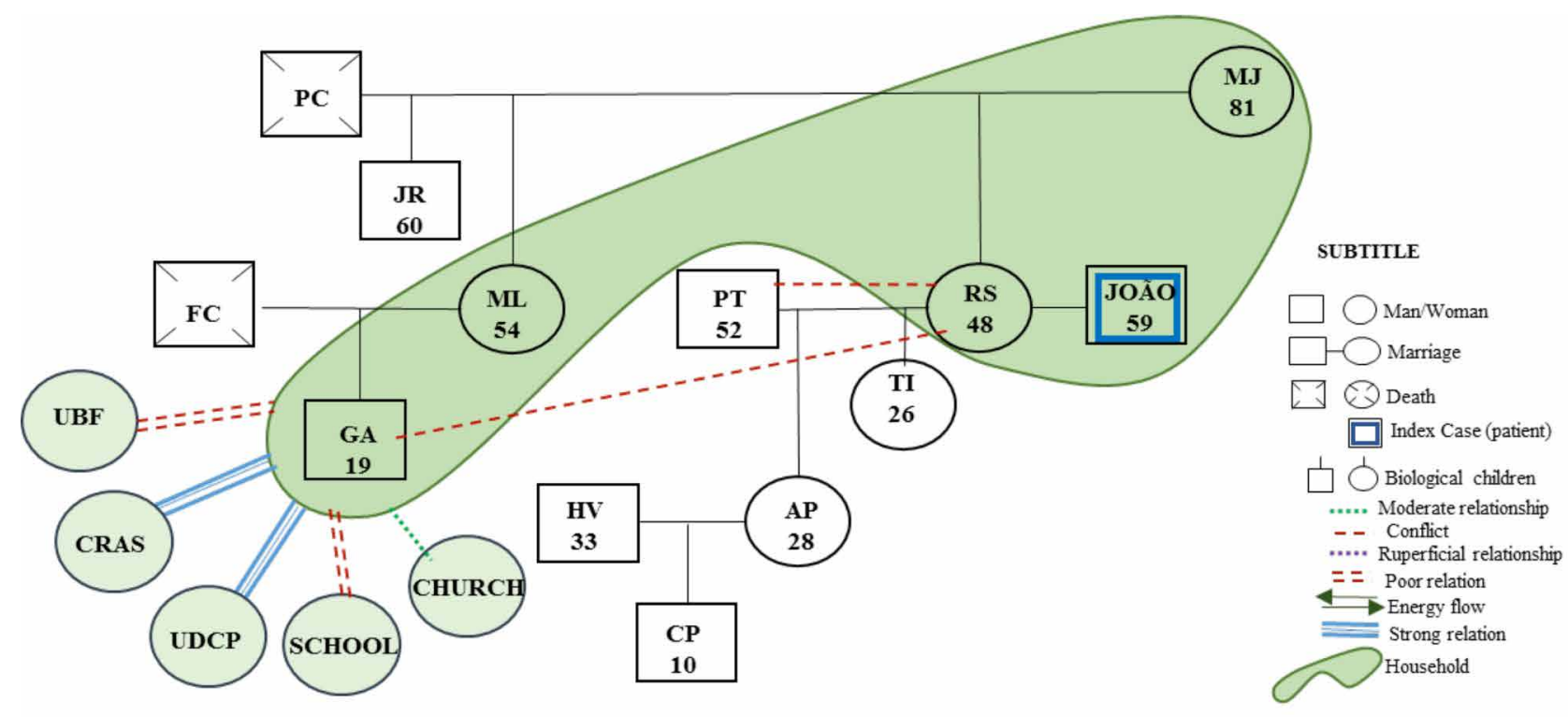

Source: Empirical material study, Recife/Pernambuco, Brazil, 2014. 
the Reference Center for Social Assistance (RCSA). As for the family context structure, according to RS, they are all Catholics and have a moderate relationship with Church, Mrs. RS also reports that have poor relations with the Health Unit Family and School.

Figure 2 highlights the genogram and eco-map in family 2 of the patient Mrs. RAL (index case). She is a native of Recife/Pernambuco, she is 53 years old, widow and evangelical. She was diagnosed with malignant neoplasm of rectum, liver (stage IV) and peritoneum.

Concerning the internal structure of family 2 (Figure 2), this is classified as nuclear family since it is composed only by the patient under palliative home care, Mrs. RAL and her two sons: JA, 31 years old, male, single and JL, 26 years old, female, single (Main caregiver).

The family relationships with the most extensive systems of external family structure, regarding the family's relationship with the neighborhood, $J \mathrm{~L}$, the daughter of the patient reported that has no relationship with neighbors, her time is for the house and mother care.

$J \mathrm{~L}$, the daughter of Mrs. RAL, mentioned that after diagnosis of the disease her mother was very sad and does not accept visits from friends; however, before getting sick she was a cheerful person and liked carnival and many friends. Regarding the health system, there is a strong relationship between the family and the PCUP, especially with the nurse who performs almost weekly visits. JL reported that relations with the USF team were weak.

Concerning the family context structure, according to Mrs. RAL, the family is evangelical and has a strong link with religion; is in the church that all seek support and peace of mind.

The genogram and the eco-map (Figure 3) depict the structure of family 3 of the patient Mrs. FAC (index case). She is a native of Recife/Pernambuco; she is 88 years old and a widow. She was diagnosed with Alzheimer's disease.

Regarding the internal structure of the cited family 3 (Figure 3), it is composed by the palliative care patient FAC, by the daughter MC (Main caregiver) 59 years old, married to PA with 68 years old, the couple has an adolescent daughter FC with 19 years old and a son LC, young with 26 years old. The family is characterized as extensive.

The family relationships with larger systems of external family structure, regarding the family relationship with the neighborhood, MC cited is not

Figure 2. Genogram and Eco-map of Family 2.
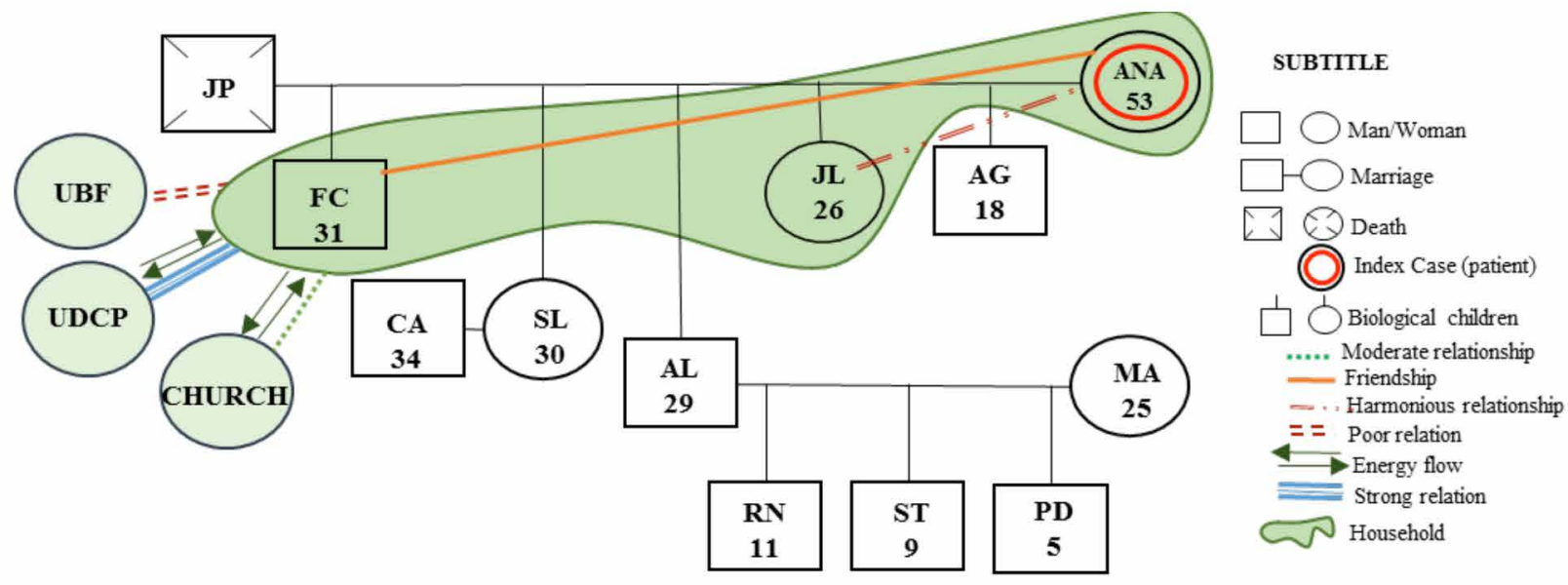

Source: Empirical material study, Recife/Pernambuco, Brazil, 2014. 
Figure 3. Genogram and Eco-map of Family 3.

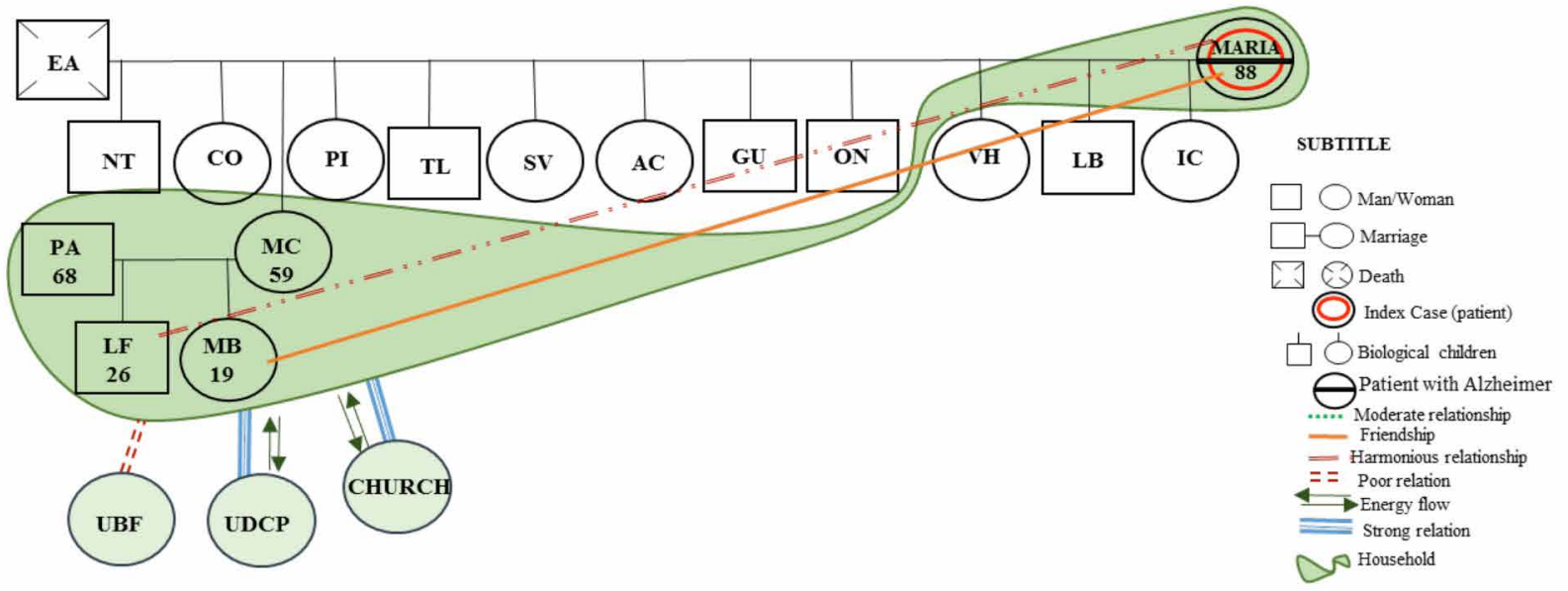

Source: Empirical material study, Recife/Pernambuco, Brazil, 2014.

necessary since they are complementary, never needed to be at neighbors home. Regarding the support network in health, which can be viewed in the eco-map (Figure 3), the family has a very strong relationship with the PCUP. On the other hand, $M C$ reports that have poor relations with the Health Unit Family.

Concerning the family context structure, according to FAC, they are all Catholics and have a strong relationship, and a steady flow of energy to the Church also pointed out that the prayers found support for coping with the disease.

The highlighted figure expresses the genogram and the eco-map of family 4, Mr. RJP (index case). $\mathrm{He}$ is a native of Recife/Pernambuco, divorced and has 49 years old. He was diagnosed with amyotrophic lateral Sclerosis.

Regarding the internal structure of the family 4, this consists of RJP patient, his wife FL (Main caregiver) 37 years old, two daughters of 10 and 5 years and a wife's niece. Characterization of a nuclear family.

FL reported that she was no longer married to RJP when he was diagnosed with the disease but noting the need for care and the severity of the illness; she brought him to her home. She cited that feels tired taking care of the former spouse because she works as a housekeeper, even with the help of her niece and a friend in the care of RJP patient. She said that was exhausted with the situation.

Family relationships with larger systems of external family structure, FL said she has no time to have relations with the neighborhood. Regarding health support network, the family has a very strong relationship covering the PCUP and BHU. FL reports that do not have time to go to meetings of parents and teachers in the school, resulting in a weak relationship. There is also a strong relationship between the football team and the family so that Mr. RJP is very happy and thrilled with the visit of their favorite team members.

Regarding the family context structure, according to Mr. RJP and his wife FL, the family has a weak relationship with the church. They like to pray at home seeking support and peace of mind.

The genogram and the eco-map shown in Figure 5, includes the MDLR patient's family structure (index case). She is a native of Recife/Pernambuco, she has 90 years old and is a widow. She was diagnosed with Alzheimer's. 
Figure 4. Genogram and Eco-map of Family 4.

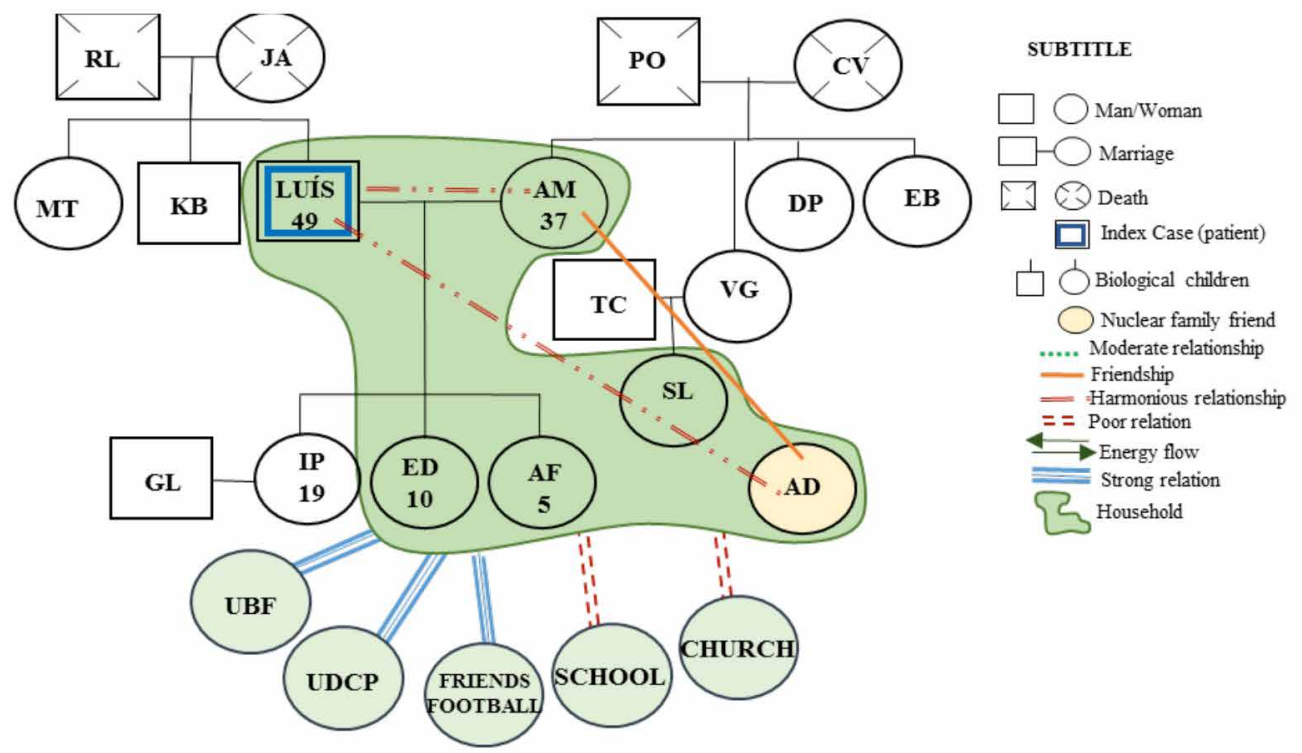

Source: Empirical material study, Recife/Pernambuco, Brazil, 2014.

Figure 5. Genogram and Eco-map of Family 5.

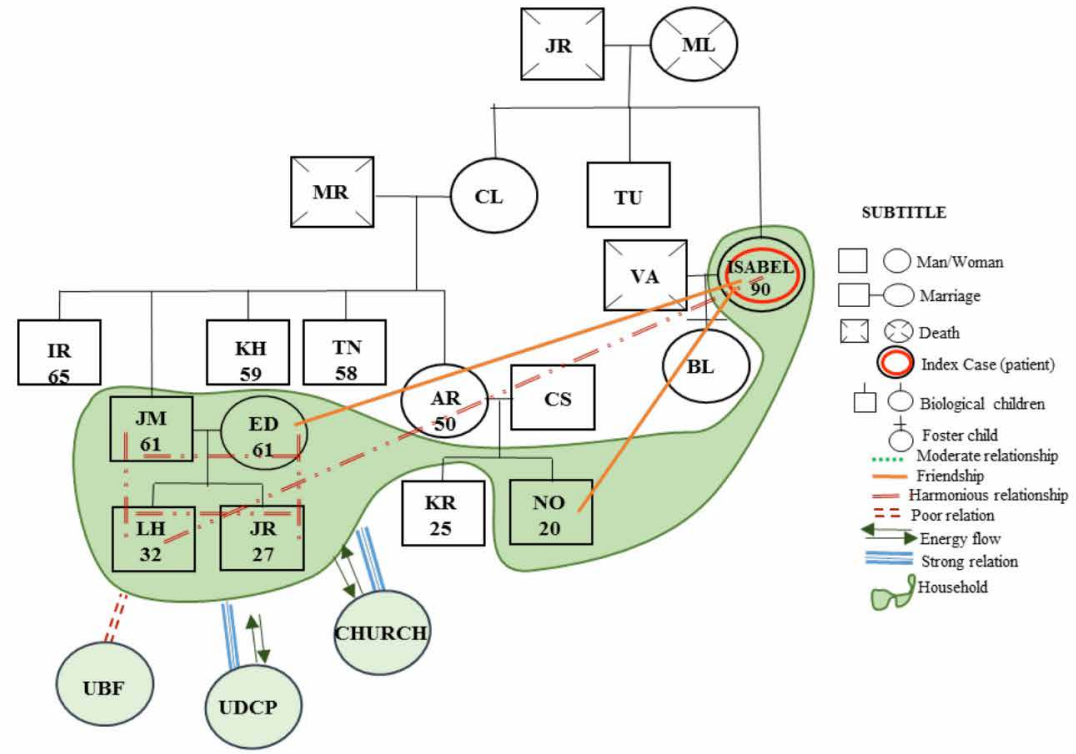

Source: Empirical material study, Recife/Pernambuco, Brazil, 2014.

Concerning the internal structure of family 5, is composed by the patient under palliative care MDLR, who lives with her nephew PRR, 61 years old (responsible family caregiver), married with MFR,
61 years old, who has two children DR with 32 years old, JR with 27 years old and a nephew NRNP, 20 years old. The family nucleus is characterized as extended family. 
MDLR has an adopted daughter, with which she has no more affective relationship. Nieces help when is necessary, the family has a housekeeper who helps in the care of Mrs. MDLR.

The family relationships with larger systems of external family structure, regarding the family relationship with the neighborhood, are nonexistent. As for the health support network, the family has a very strong relationship, harmonious and with a constant flow of energy between them and the PCUP. PRR reported that had poor relations with the Health Unit Family.

Concerning the family context structure, according to PRR, all are Catholics and have strong ties to the church, going to Mass whenever possible and is in prayer that strengthens the spirit founding support to face the difficulties.

\section{Discussion}

The family has always been defined as a group of people related by marriage and filiation, even by the succession of descendant's individuals to each other [11]. However, in contemporary times, the family is composed of generations of different roles and functions, i.e., are new forms of grouping. According to the authors of the Calgary Family Assessment Model "family is who its members say who are" [7:54]. In this perspective, family is defended as a group of people linked by biological and emotional bonds, involved and dedicated to each other to participate in each other's lives. [12]

Regarding the definition of Structural Category according to the Calgary Model, this is composed of sub-categories: internal structure, external structure and context [7]. In this sense, from this research it was possible to know in addition to the members of the families included in this study, the emotional bond between its members, comparing the relationship with people outside the family as well as the context in which each family is exposed. As for the internal structure, it consists of six sub-categories: family composition, gender, sexual orientation, birth order, subsystems and limits [7].

About the internal structure, it was observed that, of the five families participating in the study, most of them (families 1, 3 and 5) are close to what might be called extensive or extended family. As for the other two families forming part of this study, one may be considered mononuclear (Family 2) given that only one spouse integrates its core; and the other (family 4) retains the nuclear structure, consisting of father, mother and son/daughter.

It should be noted that over the time the nuclear family undergoes transformations before the changes jobs structure; the woman's entry into the labor market; to the rural exodus; the growth of cities, and especially the family will be organized and designated as expanded or extended family [13]. The expanded or extended family extends beyond the marital union, is formed by more than one level of descendent, could cohabitate grandparents, uncles, grandchildren, cousins, in-laws, etc., and its members lives and maintains bonds of affinity and affection [14]. About subcategory genre, this is a fundamental principle of the family organization since men and women have different reactions to experiences with the world, especially related to health care of an ill being [7]. In this approach, the present study highlighted the predominance of female participation as the main caregiver of patients under palliative home care, as families 1, 2, 3, and 4 , only in the family 5 this assignment was about the responsibility of a male caregiver, the nephew of the patient. However, he had the support of two nieces and a housekeeper to collaborate in the care of her aunt Mrs. MDLR.

It is important to note that the wives of patients of (families 1 and 4), were already separated from their husbands when they knew about the diagnosis of the condition, but decided to re-establish emotional ties since they felt responsible for taking care of her husband's health at this time of finitude. 
Therefore, the evaluation of gender shows results consistent with those registered in a study that confirms that the female sex, bearing the responsibility for ensuring the family, accumulates functions being responsible both for domestic work and the care of the members in illness situation [15]. It is worth emphasize that caring for a family member without the possibility of the cure, is responsible for producing feelings of anxiety and depression as a result of care provided consistently [16].

The study shows that the caregiver function, although recognized as important in the treatment, adversely affects the individual so that the caregiver can manifest physical and emotional burden, especially when this assistance is performed at home environment [17].

The physical and mental caregiver overload is related to some characteristics that favor the onset of this symptom, such as being female, the degree of family addiction to the member being attended and the fact of being responsible alone for the assistance to the patient [18].

It is noteworthy that the role assigned to the caregiver generates impacts, sometimes negative in their life especially by the lack of proper guidance in the implementation of care, changes in family daily and personal routine, support absence. [19]

The study highlights that the attempt to remedy these problems is essential to link the caregiver with other family members as well as the health team that provides assistance to terminally ill patients as a way to think of more effective actions that can minimize these barriers [17]. Therefore, it is essential that health professionals must be responsible with the family caregiver, an essential member in care to chronic patients who are at home [18].

About the subcategory sexual orientation, any family alluded it. But as the birth order, which refers to the position of children in the family, this was essential for the development of the genogram. It should be noted that for the preparation of genogram, symbols and codes that follow a pattern are used, such as birth order is always from the eldest to the youngest (left to right); and when completed, it allows ascertaining clearly which compose the family. Its use promotes understanding of the dynamics and family functioning.

The subsystems identified in the internal structural evaluation refer to the relations between the members of each familiar nucleus, mostly due to the preservation of family unity and implementation of patient care in palliative care at home and a strong relationship of dependency is evident in family 2, characterizing a mother-children system where the loss of the mother will be responsible for great suffering among their children as evidenced by one of them and main caregiver, saying that they will have difficulty accepting their mother's death.

This shows how difficult it is to accept the diagnosis of a disease that has no possibility of healing therapy and reveals the complexity of dealing with the finitude process of someone significant as the mother, figure of reference and affection.

Regarding the limits that the familiar internal structure refers to the rules of the families, which in turn need to be flexible and changeable to not negatively influence the systems, family 4 shows that at the beginning the wife took care full-time of the husband but perceiving that needed to work to assist the costs, has included her sister, her friend and niece in care who have started to collaborate in the family operation.

The external structure includes the extended family defined as the family of origin, procreation, adopted and from the current generation and the broader systems [7]. There was, in the family 5 a foster daughter that moved away when realized the seriousness of the disease is claiming she had no responsibility for the care of her mother, leaving this task on the incumbency of a nephew and other MDLR's daughters (index case).

Concerning the larger systems, these include social institutions and people with whom the family has a significant contact, such as other families, 
health systems, bodies that promote well-being, among others, which in turn are essential elements for the development of the eco-map [7].

About these systems, all the families who claim to have a very strong bond with the institution reported the PCUP. The family 1 reported the Reference Center for social assistance, which is very useful in assisting a member with mental problems.

Regarding the structural context evaluation, it was observed that most families regard a strong bond with God, reinforcing the importance of religion as a source of strength and faith to face the illness of a family being.

Thus, it is evident that faith and religion are in important support sources for the family in the face of the disease process and impending death as these can act as a refuge in adversity, such as relief, solace and comfort in difficult situations and they can be understood as a way of overcoming traumatic moments [4].

Concerning social class, which also makes up the context of structural assessment category, the families and 2 and 4 evidenced low financial resources and claim that the illness and home care increased expenses in the family. This fact coincides with the finding of research that depicts that it is proven that when this assistance is performed at home, it is possible to generate financial expenses to meet the care demands. [17]

Regarding the environment, this is related to the broader community, neighborhood and home, including elements such as school, public transport that influence family functioning [7].

As for the neighborhood, family 1 reports have no relationship since moved recently, families 2 and 3 states that have little contact with neighbors, 4 and 5 have a non-existent relationship with the neighborhood. About the relationship with school, families 1 and 4 shows weak link, the first because his nephew had left the school and the last because the mother does not have time to attend the meetings of parents and teachers.
As the Family Health Unit and the relationship with families, family 1 has a weak link, 2, 3 and 5 non-existent, and only family 4 has a strong relationship. Regarding the Unit of Palliative Care and Pain Treatment, all have a very strong bond. These results were also observed in a survey that highlighted the need for the integration of health services in the family to facilitate the adequacy of their assistance to the reality of the family [15].

These bonds expressed in the genogram and the eco-map allows verifying the usefulness of these instruments, which help in identifying interpersonal relationships, as well as support networks that can help families. It is important to highlight that these instruments can be developed in different health care settings, from the hospital setting to the home [7].

The study noted that for nurses to attend the family is a continuous learning; one side must respect the uniqueness of each family, and in return, the unique view and holistic care that must be returned to be careful. And for one who starts the professional activities are even greater challenges, since at the beginning may have resistance, whether in structural, environmental or related to unpreparedness to deal with the pain and suffering of the family [20].

The study also points out that the principles added to the individual and collective values will guide the making of the nurse, turning each day the meaning of care, especially those associated with family care before the anguish of a loved one in palliative care. These elements are present for the professional who start taking care of these families because beliefs about the finitude process are still very strong and end up affecting the care process [20].

There is no denying about the contribution of the scientific production of Brazilian nurses directed to family care. [21] Thus, the reflections as the structural application of Calgary Family Assessment Model of this study contribute to advances in nursing care 
actions to the patient in palliative home care at different times resulting in the final stage of life. In this way, special attention to the humanized care, guided by nursing theoretical models, promote the process of perception and perspective of the human and nursing professional as a whole.

\section{Final considerations}

Understanding the families of patients in palliative home care, from the structural CFAM evaluation, which includes its intra- and extra-family relationships collaborates in the implementation of quality care focused on adaptation and coping limitations and afflictions that have the family structures.

From this study, the value of using the genogram and the eco-map can be recognized, as it provides a closer approximation of the nurse with the family of patients in palliative home care, contributing both to better performance as to identify their actual and potential needs.

The survey revealed in its results that it is possible to realize the importance of affective relations between the members of each family nucleus, from the diagnosis and evolution of the patient's disease in palliative care. However, the external family structure, regarding the family relationship with the neighborhood is nonexistent, showing a gap in care as important social support in any situation or condition of life.

Facing the reality presented by the participants of this study, it is evident the strong bond between all the families and staff of palliative home care, revealing that the professionals who make up the PCUP are concerned about the quality of death and the quality of teamwork and support to families that are in this difficult and inevitable existential circumstances.

It was observed that each family has strengths, such as faith, even in the face of the faced health problems. The structural context evaluation showed that most families have a strong bond with God, which reinforces and reaffirms the importance of religion as a source of strength and faith to face the illness of a family being. Although not disease healing possibility represents a constant threat to the family's plans, it is expected that it will be able to explore and mobilize intrinsic and extrinsic resources to overcome positively to the stressor.

This waked up the need to see the family as the focus of care, once the CFAM proved to be an effective instrument to deal with the patient's family under palliative home care, allowing a wide view of its internal, external relations and context, in addition to the situations of each member, providing a driven care in supporting, understanding, support treatment, and essentially, the strengthening of family bonds, also helping families to seek their own solutions to the problems they experience in everyday life care to their loved one at home.

\section{References}

1. Diniz MH. Curso de Direito Civil Brasileiro.Direito de Família.Vol. 5.28. ed. São Paulo: Editora Saraiva, 2013.

2. Figueiredo MHJS, Martins MMFS. Avaliação familiar: do Modelo Calgary de Avaliação da Família aos focos da prática de enfermagem. Cien Cuid Saude. 2010; 9(3):552-9.

3. Silva ÍR, Sousa FGM, Santos MH, Cunha CLF, Silva TP, Barbosa DC, Rev Rene, Fortaleza, 2011 out/dez; 12(4):783-9.

4. Sanches MVP, Nascimento LC, Lima RAG. Crianças e adolescentes com câncer em cuidados paliativos: experiência de familiares. Rev Bras Enferm. 2014; 67(1): 28-35.

5. Ribeiro AL, Almeida CSL, Reticena KO, Maia MRG, Sales CAAline Lima Ribeiro, Carla Simone Leite de Almeida, Kesley de Oliveira Reticena, Maria Rita Guimarães Maia, Catarina Aparecida Sales. A enfermagem no cuidado paliativo domiciliar: o olhar do familiar do doente com câncer. Rev Rene. 2014; 15(3):499-507.

6. Radbruch L, Payne S. White paper on standards and norms for hospice and palliative care in Europe: part 2 - Recommendations from the European Association for Palliative Care. Eur J Palliat Care. 2010; 17 (1): 22-33

7. Wright LM; Leahey M. Enfermeiras e famílias. guia para avaliação e intervenções na família. 5a edição. São Paulo: Rocha. 2012.

8. Tong A, Sainsbury P, Craigh J. Consolidated criteria for reporting qualitative research (COREQ): a 32-item checklist for interviews 
and focus groups. International Journal for Quality in Health Care, v. 19, n. 6, p. 349-357, 2007.

9. Minayo MCS. O desafio do conhecimento: pesquisa qualitativa em saúde. 12a edição. São Paulo: Hucitec; 2012.

10. Brasil. Ministério da Saúde (BR), Conselho Nacional de Saúde. Resolução 466/2012. Brasília: MS;. Disponível em: http:// conselho.saude.gov.br/resolucoes/2012/Reso466.pdf.

11. Conti, Cecilia, and María Eugenia Ferraris. "Familias: aportes a la construcción de un abordaje integral de la disfunción familiar." Archivos de Medicina Familiar y General 11.2 (2014).

12. Stamm B, Rosa BVC, Begnini D, Girardon-Perlini NMO. Health interventions with families experiencing illness by cancer: an integrative review. Rev Enferm UFPE On Line. [Internet] 2014 [cited 2016 mar 21]; 8(11):4139-49. Available from: http://www. revista.ufpe.br/revistaenfermagem/index.php/revista/article/ view/5407/pdf_6651

13. Whitaker DCA. O idoso na contemporaneidade: a necessidade de se educar a sociedade para as exigências desse novo ator social, titular de direitos. Cadernos Cedes, p. 179-188, 2010.

14. Caniço $\mathrm{H}$ et al. Novos Tipos de Família. Plano de Cuidados. Imprensa da Univ. de Coimbra, 2010.

15. Leite MT, Flores JS, Hildebrandt LM et al. Idosos mais velhos no domicílio: a família como unidade de cuidado. R. pesq.: cuid. fundam. online 2012. out./dez. 4(4):2816-31.
16. Silva CF, Passos VMA., Barreto SM. Frequência e repercussão da sobrecarga de cuidadores familiares com demência. Rev.Bras. Geriat.Gerontol. 2012. 15(4):707-734.

17. Oliveira SG, Garcia RP, Quintana AM, Budó MLD, Wünsch S, Silveira CL. Dinâmica de organização dos cuidadores familiares do paciente terminal em internação domiciliar. Cienc Cuid Saude. 2011;10(4):674-681.

18. Vieira L, Nobre JRS, Bastos CCBC, Tavares KO. Cuidar de um familiar idoso dependente no domicílio: reflexões para os profissionais da saúde. Rev. Bras. Geriatr. Gerontol., Rio de Janeiro, 2012; 15(2):255-263.

19. Wachholz PA, Santos RCC, Wolf LSP. Reconhecendo a sobrecarga e a qualidade de vida de cuidadores familiares de idosos frágeis. Rev. bras. geriatr. gerontol. [Internet]. 2013 Sep [cited 2016 Apr 26] ; 16(3): 513-526. Available from: http://www.scielo.br/scielo.php?script=sci_arttext\&pid=\$180998232013000300010\&lng=en.

20. Fernandes MFP, Komessu JH. Desafios do enfermeiro diante da dor e do sofrimento da família de pacientes fora de possibilidades terapêuticas. Revista da Escola de Enfermagem da USP, v. 47, n. 1, p. 250-257, 2013.

21. Nascimento LC, Dantas IRO, Andrade RD, Mello DF. Genograma e ecomapa: contribuições da enfermagem Brasileira. Texto Contexto Enferm, Florianópolis, 2014 Jan-Mar; 23(1): 211-20.
Publish in International Archives of Medicine

International Archives of Medicine is an open access journal publishing articles encompassing all aspects of medical science and clinical practice. IAM is considered a megajournal with independent sections on all areas of medicine. IAM is a really international journal with authors and board members from all around the world. The journal is widely indexed and classified Q1 in category Medicine. 